\title{
Sustainable crossbreeding systems of beef cattle in the era of climate change
}

\author{
M.C. Mokolobate ${ }^{1,2 \#}$, A. Theunissen ${ }^{1,3}$, M.M Scholtz ${ }^{1,2}$ \& F.W.C Neser ${ }^{2}$ \\ ${ }^{1}$ ARC Animal Production Institute, Irene, South Africa; ${ }^{2}$ Department of Animal, Wildlife and Grassland Sciences, \\ University of the Free State, Bloemfontein, South Africa; ${ }^{3}$ Northern Cape Department of Agricultural, Land Reform and \\ Rural Development, Private Bag X9, Jan Kempdorp 8550, South Africa
}

(Received 4 January 2014; Accepted 5 June 2014; First published online 16 August 2014)

Copyright resides with the authors in terms of the Creative Commons Attribution 2.5 South African Licence.
See: http://creativecommons.org/licenses/by/2.5/za
Condition of use: The user may copy, distribute, transmit and adapt the work, but must recognise the authors and the South African
Journal of Animal Science.

\begin{abstract}
Beef cattle are unique, because they not only suffer from climate change, but they also contribute to climate change through the emission of greenhouse gases (GHG). Mitigation and adaptation strategies are therefore needed. An effective way to reduce the carbon footprint from beef cattle would be to reduce the numbers and increase the production per animal, thereby improving their productivity. Sustainable crossbreeding systems can be an effective way to reduce GHG, as it has been shown to increase production. There are a wide range of different cattle breeds in South Africa which can be optimally utilized for effective and sustainable crossbreeding. This paper reports on the effects of crossbreeding on the kilogram calf weaned per Large Stock Unit (kgC/LSU) for 29 genotypes. These genotypes were formed by crossing Afrikaner (A) cows with Brahman (B), Charolais (C), Hereford (H) and Simmentaler (S) bulls and by back-crossing the $\mathrm{F} 1$ cows to the sire lines. A LSU is the equivalent of an ox of $450 \mathrm{~kg}$ with a daily weight gain of $500 \mathrm{~g}$ on grass pastures with a mean digestible energy (DE) content of $55 \%$ and a requirement of 75 MJ metabolizable energy (ME). Crossbreeding with $A$ as dam line increased the $\mathrm{kgC/LSU}$ on average by 8 $\mathrm{kg}(+6 \%)$ - with the CA cross producing the most $\mathrm{kgC/LSU}(+8 \%)$ above that of the AA. The BA dam in crosses with $\mathrm{C}, \mathrm{H}$ and $\mathrm{S}$, increased $\mathrm{kgC} / \mathrm{LSU}$ on average by $26 \mathrm{~kg}(+18 \%)$ above that of the AA dam, with the $\mathrm{H} \times$ BA cross, producing the most $\mathrm{kgC} / \mathrm{LSU}(+21 \%)$. The BA, CA, HA and SA F1 dam lines, back-crossed to the sire line breeds, increased $\mathrm{kgC} / \mathrm{LSU}$ on average by $30 \mathrm{~kg}(21 \%), 21 \mathrm{~kg}(15 \%), 19 \mathrm{~kg}(13 \%)$ and $26 \mathrm{~kg}$ $(18 \%)$ above the that of the AA, respectively. The big differences between breeds in $\mathrm{kgC/LSU}$ provide the opportunity to facilitate effective crossbreeding that can be useful in the era of climate change. From this study it is clear that cow productivity can be increased by up to $21 \%$ through properly designed, sustainable crossbreeding systems, thereby reducing the carbon footprint of beef production.
\end{abstract}

Keywords: Carbon footprint, cow productivity, kilogram calf, production systems

\# Corresponding author: MokolobateM@arc.agric.za

\section{Introduction}

Livestock, and likewise beef cattle, are unique in the sense that they not only suffer from climate change, but also contribute to climate change through the emission of greenhouse gases (GHG). Livestock accounts for about $65 \%$ of the total agricultural $\mathrm{GHG}\left(\mathrm{CO}_{2}\right.$ equivalent) of which enteric fermentation (animal digestive tract) accounts for $90 \%$. Mitigation and adaptation strategies therefore need to be put in place if climate change that is related to animal production is to be contained within certain limits (Scholtz et al., 2013). An effective way to reduce the carbon footprint of beef cattle is to reduce the numbers and increase the production per animal, thereby improving their production efficiency.

Genetic improvement is a possible mitigation option whereby production efficiency can be improved (Wall et al., 2010). There is sufficient genetic variation in South Africa's cattle genetic resources, including indigenous genotypes, to facilitate breeding for improved production efficiency. Improved production efficiency can also be attained through effective crossbreeding systems. The benefits of effective crossbreeding have thus already been reported in a number of studies (Koch et al., 1978; Cundiff et al., 1991, Gregory et al., 1992; Williams et al., 2010). 


\section{Materials and Methods}

The least square means of cow weight (CW) and weaning weight (WW) from a crossbreeding programme using 29 genotypes as reported by Theunissen (2011) were used to estimate cow productivity. These genotypes were formed by crossing Afrikaner (A) cows with Brahman (B), Charolais (C), Hereford (H) and Simmentaler (S) bulls and by back-crossing the F1 cows to the sire line breeds.

Cow productivity was defined as kilogram calf weaned/Large Stock Unit (LSU) according to Mokolobate et al. (2013). Meissner et al. (1983) defined a LSU as the equivalent of an ox with a weight of $450 \mathrm{~kg}$ and a weight gain of $500 \mathrm{~g}$ per day on grass pastures with a mean digestible energy (DE) content of $55 \%$, with a requirement of $75 \mathrm{MJ}$ metabolizable energy (ME). The following equation, developed by Neser et al. (2013), was used to calculate the LSU for different weights of the lactating cows:

$$
y=0.000008 x^{2}-0.0054 x+2.13
$$

where $\mathrm{y}=$ LSU units and $\mathrm{x}=$ cow weight.

The weaning weights and cow weights for the 29 different genotypes are set out in Tables 1 and 2.

Table 1 Least square means for weaning weights $(\mathrm{kg})$ of calves, combined in the different sire and dam breed groups

\begin{tabular}{|c|c|c|c|c|c|}
\hline \multirow[b]{2}{*}{ Dam breed } & \multicolumn{5}{|c|}{ Sire Breed } \\
\hline & $\begin{array}{l}\text { Afrikaner } \\
\text { (A) }\end{array}$ & $\begin{array}{c}\text { Brahman } \\
\text { (B) }\end{array}$ & $\begin{array}{l}\text { Charoloais } \\
\text { (C) }\end{array}$ & $\begin{array}{l}\text { Hereford } \\
(\mathrm{H})\end{array}$ & $\begin{array}{c}\text { Simmentaler } \\
\text { (S) }\end{array}$ \\
\hline A & $\begin{array}{l}184 \\
(41)\end{array}$ & $\begin{array}{l}206 \\
(29)\end{array}$ & $\begin{array}{l}212 \\
(24)\end{array}$ & $\begin{array}{l}195 \\
(31)\end{array}$ & $\begin{array}{l}210 \\
(32)\end{array}$ \\
\hline B & & $\begin{array}{l}199 \\
(24)\end{array}$ & & & \\
\hline C & & & $\begin{array}{l}222 \\
(40)\end{array}$ & & \\
\hline $\mathrm{H}$ & & & & $\begin{array}{l}179 \\
(44)\end{array}$ & \\
\hline $\mathrm{s}$ & & & & & $\begin{array}{l}234 \\
(31)\end{array}$ \\
\hline BA & $\begin{array}{l}200 \\
(23)\end{array}$ & $\begin{array}{l}207 \\
(17)\end{array}$ & $\begin{array}{l}238 \\
(20)\end{array}$ & $\begin{array}{l}224 \\
(21)\end{array}$ & $\begin{array}{l}237 \\
(19)\end{array}$ \\
\hline CA & $\begin{array}{l}216 \\
(29)\end{array}$ & $\begin{array}{l}244 \\
(22)\end{array}$ & $\begin{array}{l}235 \\
(23)\end{array}$ & $\begin{array}{l}233 \\
(24)\end{array}$ & $\begin{array}{l}241 \\
(26)\end{array}$ \\
\hline HA & $\begin{array}{l}202 \\
(21)\end{array}$ & $\begin{array}{l}221 \\
(19)\end{array}$ & $\begin{array}{l}228 \\
(16)\end{array}$ & $\begin{array}{l}210 \\
(16)\end{array}$ & $\begin{array}{l}230 \\
(26)\end{array}$ \\
\hline SA & $\begin{array}{l}220 \\
(20)\end{array}$ & $\begin{array}{l}237 \\
(28)\end{array}$ & $\begin{array}{l}245 \\
(25)\end{array}$ & $\begin{array}{l}230 \\
(20)\end{array}$ & $\begin{array}{l}229 \\
(28)\end{array}$ \\
\hline
\end{tabular}

( ) Number of calves in brackets

\section{Results and Discussion}

The results obtained by crossbreeding the Brahman (B), Charolais (C), Hereford $(H)$ and Simmentaler (S) as sire line breeds with the Afrikaner (A) and F1 cow genotypes as dam lines (Theunissen, 2011), were used to estimate cow productivity. In this study kilogram calf weaned/Large Stock Unit ( $\mathrm{kgC} / \mathrm{LSU}$ ) was used as an estimation of cow productivity. This estimated cow productivity for the different genotypes is set out in Table 3, with the percentage deviation from the Afrikaner genotype in brackets. 
Table 2 Least square means for cow weights $(\mathrm{kg})$ in the different sire and dam breed groups

\begin{tabular}{|c|c|c|c|c|c|}
\hline \multirow[b]{2}{*}{ Dam breed } & \multicolumn{5}{|c|}{ Sire Breed } \\
\hline & $\begin{array}{l}\text { Afrikaner } \\
\text { (A) }\end{array}$ & $\begin{array}{l}\text { Brahman } \\
\text { (B) }\end{array}$ & $\begin{array}{c}\text { Charolais } \\
\text { (C) }\end{array}$ & $\begin{array}{l}\text { Hereford } \\
\text { (H) }\end{array}$ & $\begin{array}{c}\text { Simmentaler } \\
\text { (S) }\end{array}$ \\
\hline A & 435 & 488 & 497 & 438 & 481 \\
\hline B & & 449 & & & \\
\hline C & & & 502 & & \\
\hline $\mathrm{H}$ & & & & 407 & \\
\hline $\mathrm{S}$ & & & & & 459 \\
\hline BA & 422 & 456 & 516 & 442 & 487 \\
\hline CA & 460 & 536 & 508 & 487 & 509 \\
\hline HA & 420 & 490 & 487 & 445 & 485 \\
\hline SA & 457 & 507 & 510 & 457 & 456 \\
\hline
\end{tabular}

Table 3 The cow productivity (kgC/LSU) for the different genotypes (percentage deviation from the Afrikaner genotype in brackets)

\begin{tabular}{cccccc}
\hline \multirow{2}{*}{ Dam breed } & \multicolumn{5}{c}{ Sire Breed } \\
\cline { 2 - 6 } & $\begin{array}{c}\text { Afrikaner } \\
(\mathbf{A})\end{array}$ & $\begin{array}{c}\text { Brahman } \\
\text { (B) }\end{array}$ & $\begin{array}{c}\text { Charolais } \\
\text { (C) }\end{array}$ & $\begin{array}{c}\text { Hereford } \\
(\mathbf{H})\end{array}$ & $\begin{array}{c}\text { Simmentaler } \\
\text { (S) }\end{array}$ \\
\hline A & 142 & $147(3.5 \%)$ & $154(8.5 \%)$ & $150(5.6 \%)$ & $152(7.0 \%)$ \\
B & & $151(6.3 \%)$ & & & \\
C & & & $155(9.2 \%)$ & & \\
H & & & & $142(0.0 \%)$ & \\
S & & & & $172(21.1 \%)$ & $170(19.7 \%)$ \\
BA & $157(10.6 \%)$ & $156(9.9 \%)$ & $162(14.1 \%)$ & $172 \%)$ \\
CA & $161(13.4 \%)$ & $159(12.0 \%)$ & $162(14.1 \%)$ & $167(17.6 \%)$ & $166(16.9 \%)$ \\
HA & $160(12.7 \%)$ & $157(10.6 \%)$ & $163(14.8 \%)$ & $160(12.7 \%)$ & $165(16.2 \%)$ \\
SA & $165(16.2 \%)$ & $164(15.5 \%)$ & $168(18.3 \%)$ & $173(21.8 \%)$ & $172(21.1 \%)$ \\
\hline
\end{tabular}

Crossbreeding with $\mathrm{A}$ as dam line and $\mathrm{B}, \mathrm{C}, \mathrm{H}$, and $\mathrm{S}$ as sire lines, increased $\mathrm{kgC/LSU}$ on average by $9 \mathrm{~kg}(+6 \%)$, with the CA cross producing the most $\mathrm{kgC} / \mathrm{LSU}$ with an increase of $11 \mathrm{~kg}(+8 \%)$ above that of the AA. In the case of FI cows the SA cow produced on average the most $\mathrm{kgC/LSU}$ (an increase of between $15.5 \%$ and $21.8 \%$ ). The $A B$ dam crossbred with the $A, B, C, H$ and S, increased $\mathrm{KgClLSU}$ on average by $21.4 \mathrm{~kg}(+15 \%)$, above that of the AA dam with the $\mathrm{H} \times$ BA cross producing the most $\mathrm{kgC} / \mathrm{LSU}(+21.1 \%)$ (Table 3). These results are similar to the results of the CA and HA dams, each with an average increase of $21 \mathrm{~kg}(+15 \%)$ and $19 \mathrm{~kg}(+13 \%)$. The SA dam on average increased cow productivity by $26.4 \mathrm{~kg}(+19 \%)$. The improvement demonstrated in this study concurs with that of Schoeman (2010), which indicated that crossbreeding improves cow/calf efficiency when measured as energy requirements or input costs per $\mathrm{kg}$ of equivalent steer weight. Although the effect of heterosis on individual traits is normally relatively small, the cumulative effect on composite traits, such as weight of calf weaned per cow exposed are big (Gregory \& Cundiff, 1980; Schoeman, 2010), which explains the superiority in kgC/LSU as a composite trait.

Effective crossbreeding also makes use of breed complementarity. Complementarity refers to the phenomena where there is an advantage for a specific crossbred over that of other crossbreds. It is generally caused by the way in which two or more traits combine or complement each other to express the net merit of the animal. Breed differences in direct and maternal effects can be used to complement each other if appropriate crosses are made (Schoeman, 2010). 


\section{Conclusions}

From this study it is clear that cow productivity can be increased by up to $21 \%$ through properly designed crossbreeding systems, thereby reducing the carbon footprint of beef production. The fact that there are large differences in the $\mathrm{kgC/LSU}$ between certain genotypes, points to genetic differences and holds the potential for improvement through selection and the use of complementarity between breeds.

\section{Acknowledgement}

This work is based on research supported in part by Red Meat Research and Development South Africa and the National Research Foundation of South Africa (NRF), under grants UID 75122 and 75123. The Grant-holder acknowledges that opinions, findings and conclusions or recommendations expressed in any publication generated by the NRF-supported research are that of the authors and that the NRF accepts no liability whatsoever in this regard.

\section{References}

Cundiff, L.V., Gregory, K.E. \& Koch, R.M., 1991. Breed effects and heterosis in advanced generations of composite populations for preweaning traits of beef cattle. J. Anim. Sci. 69, 947-960.

Gregory, K.E. \& Cundiff, L.V., 1980. Crossbreeding in beef cattle: evaluation of systems. J. Anim. Sci. 54, $1224-1242$.

Gregory, K.E., Cundiff, L.V. \& Koch, R.M., 1992. Effects of breed and retained heterosis on milk yield and 200-day weight in advanced generations of composite populations of beef cattle. J. Anim. Sci. 70, 2366-2372.

Koch, R.M., Gregory, K.E., Crouse, J.D., Laster, D.B., Cundiff, L.V. \& Smith, G.M., 1978. Heterosis and Breed Maternal and Transmitted Effects in Beef Cattle IV. Carcass Traits of Steers. J. Anim. Sci. 47, 1063-1079.

Meissner, H.H., Hofmeyr, H.S., Van Rensburg, W.J.J. \& Pienaar, J.P., 1983. Classification of livestock for realistic prediction of substitution values in terms of a biologically defined Large Stock Unit. Tech. Comm. No. 175. Department of Agriculture, Pretoria.

Mokolobate, M.C., Scholtz, M.M., Mulugeta, S. \& Neser, F.W.C., 2013. Report on a breeding objective that may reduce the carbon footprint of extensive cow-calf production systems. Nat. Sci. 5, 167-171.

Neser, F.W.C., Skrypzeck, H., Jordaan, G.F. \& Schoeman, S.J., 2000. Estimates of crossbreeding parameters in a multibreed beef cattle crossbreeding project. S. Afr. J. Anim. Sci. 30, 193-203.

Schoeman, S.J., 2010. Crossbreeding in beef cattle. In: Beef Breeding in South Africa. ( $2^{\text {nd }}$ ed.). Ed: Scholtz, M.M., ARC, Pretoria, 21-32.

Scholtz, M.M., Maiwashe, A., Neser, F.W.C., Theunissen, A., Olivier, W.J., Mokolobate, M.C. \& Hendriks, J., 2013. Livestock breeding for sustainability to mitigate global warming, with the emphasis on developing countries. S. Afr. J. Anim. Sci. 43, 269-281.

Theunissen, A., 2011. Characterization of breed additive and heterosis effects in beef cattle using experimental results. M.Sc. dissertation. University of the Free State, Bloemfontein, South Africa.

Wall, E., Simm, G. \& Moran, D., 2010. Developing breeding schemes to assist mitigation of greenhouse gas emissions. Animal 4, 366-376.

Williams, J.L., Aguilar, I., Rekaya, R.R. \& Bertrand, J.K., 2010. Estimation of breed and heterosis effects for growth and carcass trait in cattle using published crossbreeding studies. J. Anim. Sci. 88, 460-466. 